\title{
Audit Committee Attributes and Internal Audit Function Effectiveness. Evidence from Zimbabwe Local Authorities
}

\author{
Moses Jachi $^{1,2^{*}} \quad$ Lucia Mandongwe ${ }^{1}$ \\ 1.Manicaland State University of Applied Sciences P. Bag 7001, Mutare, Zimbabwe \\ 2.Midlands State University P. Bag 9055, Gweru, Zimbabwe
}

\begin{abstract}
The study aimed at establishing the impact of audit committee characteristics on internal audit function effectiveness in Zimbabwe local authorities. The study used audit committee characteristics as represented by its dimensions of competence, conduct of meetings and independence as the independent variable and internal audit function effectiveness, represented by its dimensions of independence, competence and objectivity as the dependent variable. The association between the independent and dependent variables was assessed considering the effects of the regulatory environment as the mediating variable there to. Survey data was obtained from audit committee chairpersons and chief audit executives in Zimbabwean local authorities using semi-structured questionnaires. Correlation and regression analysis were used to test whether there is a relationship between audit committee characteristics and internal audit function effectiveness. The study established that audit committee membership in Zimbabwe local authorities is not subject to qualifications, experience or expertise, as such, majority of audit committees in Zimbabwe local authorities lack the required competencies to effectively execute their mandates. Correlation and regression analysis results further established that the characteristics of independence and conduct of meetings are capable of predicting the effectiveness of internal audit functions within Zimbabwe local authorities. The study recommends the inclusion of "resource persons", in form of independent professionals with financial expertise and experience within audit committees of local authorities, most preferably from the civil service, so as to fill the competency gap. The study also recommends the establishment of clearer guidelines on the operation of audit committees within Zimbabwe local authorities to help in ensuring the committees' independence and objectiveness is guaranteed thereby strengthening their oversight role.
\end{abstract}

Keywords: Audit committee, Attributes, Internal audit function, Effectiveness

DOI: $10.7176 /$ RJFA/10-24-07

Publication date: December $31^{\text {st }} 2019$

\section{Introduction}

Professional and academic literature accentuates the importance of audit committees as a relevant component of modern corporate governance structures, particularly within public sector organizations (Goddard \& Masters, 2000; Psaros \& Seamer, 2004; Van der Nest, 2005; Apollo, 2008). It notes the significant structural incentives associated with audit committees, centered on their potential to minimize agency costs (Jensen \& Meckling, 1976; Fama \& Jensen, 1983). Audit committees were first introduced by the Great Western Railways in the United Kingdom in 1872 (Max, 2009), this original concept of audit committees was meant to enhance external auditor independence. However, with developments in civilization which came with commensurate corporate governance complexities, their role scope broadened to encompass working with internal audit and management to enhance corporate governance and financial reporting processes (Max, 2009).

Based on the premises of the agency theory, opportunistic behaviour born out of the inevitable conflict between management and shareholders often motivates managers to act in their own best interests and against those of shareholders (Jensen \& Meckling, 1976; Dellaportas, et al., 2012). Therefore, in an environment without monitoring tools and effective market regulation, managers are more likely to deviate from protecting the shareholders' interests (Turley \& Zaman, 2004; Al-Matari, et al., 2012). Thus, the existence of successful and effective corporate governance practices and structures within organizations, such as the existence of an audit committee is essentially meant to reduce such conflicts (Al-Matari, 2013). An important aspect of audit committees is their impact on internal audit. The potential for an audit committee to influence a number of factors concerning internal audit is asserted in academic literature, professional literature and policy documents. Previous studies however report mixed results on the relationship between audit committee characteristics and various attributes and results of an organization's governance processes (Kallamu \& Saat, 2015; Zibra, et al., 2016). Some scholars argue that the adoption of audit committees is usually primarily symbolical (Kalbers \& Fogarty, 1993) and that the benefits associated with them are more rhetoric than substance (DeZoort, 1997), as many audit committee members lack critical attributes such as independence, expertise and experience in oversight (Cohen, et al., 2002; Guy \& Zeff, 2002).

There is limited evidence on the role of audit committees on the effectiveness of internal audit functions, particularly in the context of developing countries, as most studies on audit committee focused on its impact on 
firm performance (Al-Matari, et al., 2012; Ghabayen, 2012), corporate disclosure (Al-Moataz \& Hussainey, 2012), quality of financial reports (Rabab'ah, et al., 2017) and quality of external audit (Habbash, 2015). Alqatamin (2018) conducted a study examining the effects of audit committee characteristics on a sample of 165 non-financial companies listed in the Jordanian stock market. He found that the audit committee size, independence, and gender diversity are positively associated with firm performance (Alqatamin, 2018). Kallam and Saart (2015) investigated whether audit committee attributes impact performance of companies listed in the Malaysian stock market. They reported a significant positive association between independence attribute of audit committees and profitability and a negative association between the dual membership of directors and audit and nomination committees with profitability (Kallamu \& Saat, 2015). Al-Matari et al (2012) reported no association between the size attribute of audit committees and firm performance of 135 firms listed in the Saudi stock market in 2011 (Al-Matari, et al., 2012). In a closely related study, Ghabayen (2012) examined whether there is a relationship between the size and composition of audit committees and size and composition of the board with the firm performance of 102 non-financial firms listed in the Saudi stock market in 2011. He reported no effect of the size and composition of audit committees and the size of the board and negative effect of board composition on firm performance measured by return on assets (ROA) (Ghabayen, 2012).

Examining the association between firm performance and characteristics of audit committees in nonfinancial firms listed in the Omani stock market during the period 2011 to 2012, Al-Matari et al (2014) reported a positive non-significant association between the size and independence of audit committees and firm performance and a negative relationship between audit committees meetings and firm performance (Al-Matari, et al., 2014). In a different environment, Hsu \& Petchsakulwong (2010) examined the association between attributes of the audit committees and efficiency performance of Thai non-life insurance firms from $2000-2007$. They reported a negative association between the frequency of meetings of audit committees and efficiency performance (Hsu \& Petchsakulwong, 2010). Chan et al (2011) investigated the structural and operational characteristics of audit committees in Hong Kong by examining disclosures of 223 listed companies. They reported that the independence and financial expertise of audit committees have no influence on the value of firms because of inadequacy of resources available to audit committees (Chan, et al., 2011). Looking into the monitoring role of audit committees and firm's financial reporting and disclosure, Al-Moataz \& Hussainey (2012) reported that board independence and audit committee size, company's liquidity, gearing and profitability are crucial determinants of corporate governance disclosures in Saudi listed companies (Al-Moataz \& Hussainey, 2012).

Investigating effectiveness of audit committees and earnings management practice, Badolato et al (2014) examined the impact of audit committee financial expertise on earnings management in the United States of America. Their study was based on a sample of 29073 firm year-end observations from 2001 to 2008. They found that audit committees with both financial expertise and high relative status reduces the levels of earnings management measured by accounting irregularities and abnormal accruals (Badolato, et al., 2014). Other studies also demonstrated that audit committee's expertise limits earnings management practice (Krishnan \& Visvanathan, 2008). Reporting on a study of 347 fraud cases in US, Beasley et al (2010) reported no difference between firms, irrespective of whether they were accused of fraud, with respect to their corporate governance structures (Beasley, et al., 2010). Looking into the association between the effectiveness of audit committees and the quality of internal controls, Khlif \& Samaha (2016) conducted a survey to examine the association between audit committee activities, external auditors, size and internal control quality among Egyptian companies. They reported a significant association between audit committee activities and internal control quality especially when the organization was audited by one of the big-four audit firms (Khlif \& Samaha, 2016). Lee \& Fargher (2018) investigated the oversight role of audit committees in whistle-blowing circumstances. They discovered that audit committee quality reflected by its independence, expertise and diligence is associated with a system that enhances the reception and resolution of whistle-blowing disclosures through internal controls (Lee \& Fargher, 2018). Following the premises set by the Agency theory, the effectiveness of audit committees' monitoring role depends to some extent, on the characteristics of audit committees (Herdjiono \& Sari, 2017; Alqatamin, 2018). There are several attributes that have been reported to indicate the effectiveness of audit committees, and these include independence, size, financial expertise, gender diversity and frequency of meetings.

The Zimbabwean public sector corporate governance terrain is dominated by poor corporate governance concerns that seem to be eating away the moral fabric of the sector. These corporate governance concerns include, but not limited to, manipulation, corruption, nepotism, cronyism, fraud and gross abuse of office by both political players and public administrative officers. It is worrisome however, that this corporate governance decay is transpiring in the presence of internally embedded structures aimed mainly at alleviating, and safeguarding against the same challenges and generally strengthening corporate governance, thus, the availability of audit committees and internal audit functions within respective public sector organizations. A number of reports notes key challenges of public finance management in Zimbabwe. These were identified in a Rapid Public Finance Management Assessment (2009), the Country Integrated Fiduciary Assessment (CIFA) 
(2012); and the Country Fiduciary Re-engagement Assessment or Use of Country Financial Management Systems (UCS) Assessment conducted early 2015. These reports noted common findings, identifying the presence of rampant corruption and fraud within the country's public sector, which have been established to be associated with, among other factors, the ineffectiveness of the sector's internal audit functions.

\section{Statement of the problem}

The Zimbabwean public sector has reported a number of corporate governance scandals such as corruption and fraud. Such poor corporate governance practices are being blamed for the continuously declining quality of public service delivery. A critical review of the cases and circumstances surrounding majority of the cases reveal that the situations could have been prevented if effective audit committees were in place to check on the activities of management, complementing and strengthening internal audit effectiveness. Following the agency theory, the effectiveness of audit committees' monitoring role depends, to a certain extent, on the characteristics of the audit committees (Herdjiono \& Sari, 2017; Alqatamin, 2018). However, there is limited evidence on the role of audit committees in influencing the effectiveness of internal audit particularly in the context of developing countries, as most studies on audit committees focused on its impact on firm performance (Al-Matari, et al., 2012; Ghabayen, 2012), corporate disclosures (Al-Moataz \& Hussainey, 2012), quality of financial reports (Rabab'ah, et al., 2017) and external audit quality (Habbash, 2015). This study is aimed at filling this void through an investigation in to the impact of audit committee characteristics on internal audit function effectiveness in local authorities in Zimbabwe, a developing country.

\section{Literature review}

\subsection{Agency Theory}

The agency theory is an economic theory of accountability based on the relationship between the owners of resources and those employed to manage such resources. This separation of management and ownership roles is associated with inherent potential conflicts of interests which can only be resolved or contained at a cost (Jensen \& Meckling, 1976; Fama \& Jensen, 1983). The agency theory is based on the notion that management, as an agent is usually driven by personal interests for self-enrichment, the cost of which is met by the principal. Thus, the agency theory sought to resolve the overbearing effects of such conflicting goals (Jensen \& Meckling, 1976). The pursuit for self-enrichment by the agent is associate with costs to the organization, the burden of which falls to the principal. As such, the agent cannot be trusted, hence require some form of monitoring to ensure his actions are in the best interests of the principal. The agency theory therefore provides a basis to ensure there is some form of goal congruency between the agent and the principal, through alignment of interests (Turley \& Zaman, 2004; Al-Matari, et al., 2014). Corporate governance mechanisms are therefore designed to mitigate agency costs and protect the interest of shareholders through monitoring of management activities (Al-Matari, et al., 2014). The audit committee can be considered one of the most critical components of the decision control system for internal monitoring by the board of directors (Fama \& Jensen, 1983; Al-Matari, et al., 2014). Effective monitoring entails the use of internal audit, external audit, audit committees and non-executive directors. These monitors act in the best interests of the shareholders. As a result, high audit quality involving an independent internal audit function supported by an audit committee with the suitable attributes play a significant role in reducing chances for management to peruse self-interests. Consequently, high quality audit committees are associated with effective internal audit functions. Given these agency assumptions, independent subvariables are identified with the aim of deducing associations between audit committee characteristics and internal audit function effectiveness.

\subsection{Audit committee characteristics}

The ability of an audit committee to fulfill its monitoring role hinges to some extend on its characteristics. Literature notes a number of attributes that defines an audit committee capable of effectively executing its mandate. These attributes include financial expertise, conduct of meetings and independence.

3.2.1. Audit committee financial expertise

Audit committee expertise and competencies are critical characteristics determining its success. Audit committee members are expected to have knowledge and experience of business risks, financial and accounting policies so as to effectively monitor an organization's activities (Enofe, et al., 2013). No one individual can be expected to have all the skills and competencies, however, a proper mix is advisable. A handful of studies argue that audit committees with financial expertise are associated with improved organizational performance (Hamid \& Aziz, 2012); better earnings management (Saleh, et al., 2007; Dhaliwal, et al., 2010); effective internal controls (Krishnan, 2005) and improved financial reporting outcomes (Badolato, et al., 2014). However, in contrary, some scholars established a negative relationship between audit committee expertise and organizational performance (Aldamen, et al., 2012). In Zimbabwe local authorities, audit committee membership is, in accordance with statutory requirements, strictly by members of the council (Urban Councils Act 29:15), these council members 
are democratically elected into office by virtue of political mileage and no academic or professional consideration is made. To qualify for election as a councillor, one only needs to be a citizen of Zimbabwe, above the age of eighteen years and a registered voter (Jachi \& Yona, 2019a). As such, there is high likelihood that majority of audit committee members in Zimbabwe local authorities lack the necessary skills and competencies required for effective execution of their responsibilities (Jachi \& Yona, 2019a).

3.2.2. Conduct of audit committee meetings

The conduct of audit committee meetings is an important characteristic determining its performance. The committee's monitoring role can significantly be influenced by the frequency and attendance of its meetings. When the audit committee meets frequently, members' awareness of company operations is enhanced (Vafeas, 1999), and this directly acts as an indication of the committee's activity level (Xie, et al., 2003) consequently enhancing their monitoring (Lipton \& Lorsch, 1992; Lin, et al., 2006; Jackling \& Johl, 2009) and oversight role (Alqatamin, 2018). A number of studies conducted to assess the influence of audit committee meetings established varying outcomes. Xie et al (2003) and Saleh et al (2007) established a positive association between frequency of audit committee meetings and earnings management (Xie, et al., 2003; Saleh, et al., 2007). However, Hsu \& Petchsakulwong (2010) established a negative relationship between frequency of audit committee meetings and efficiency (Hsu \& Petchsakulwong, 2010). Mohd (2011) and Al-Matari et al (2012) established an insignificant relationship between audit committee meetings and firm performance (Mohd, 2011; Al-Matari, et al., 2012). Also, Alqatamin (2018) established a lack of association between frequency of audit committee meetings and organizational performance (Alqatamin, 2018). This therefore entails that the evidence reported in previous studies on conduct of audit committee meetings is still not conclusive. In Zimbabwe local authorities, the guidelines on conduct of audit committee meetings are outlined in various pieces of legislation. The Public Finance Management Act (Chapter 22:19) specifies that audit committee meetings shall be conducted at least twice per year. However, literature recommends a minimum of four audit committee meetings per year. The Urban Councils Act (Chapter 29:15), section 97(3) further stipulates that only members of the audit committee and external auditors are entitled to attend audit committee meetings. However, According to Jachi \& Yona (2019), this requirement is not adhered to in some Zimbabwean local authorities as senior management personnel mandatorily attend audit committee meetings (Jachi \& Yona, 2019a).

3.2.3. Audit committee independence

Independence is one of the most important characteristics of an audit committee. It is a requirement that an audit committee be free from the influence of senior management (Jun Lin \& Tang, 2008; Avison \& Cowton, 2012; Larry \& Taylor, 2012). Independent audit committees are capable of resisting pressure from management (AlMatari, 2013; Kallamu \& Saat, 2015). Audit committee independence can be enhanced by having majority of members being and the chairing of the committee by independent directors who has no personal or economic ties with management (Akhigbe \& Martin, 2006; Larry \& Taylor, 2012; Nekhili, et al., 2016), thereby strengthening their monitoring role and subsequently reducing agency problems (Yeh, et al., 2011). Notwithstanding the inconclusive nature of studies conducted on audit committee independence, a handful of literature notes the importance of audit committee independence in enhancing organizational performance (Kallamu \& Saat, 2015; Naimah, 2017; Alqatamin, 2018), and audit quality (Abbott \& Parker, 2000; Abbott, et al., 2003; Khlif \& Samaha, 2016; Lee \& Fargher, 2018). However, Shamar et al (2009) argued that there is a downside risk associated with independent audit committees, noting that the committee members will be completely devolved from management and therefore have less exposure to critical issues affecting the daily operations of the organization (Sharma, et al., 2009). Zimbabwean local authorities are run on a committee basis, as such, it is a statutory requirement, as pronounced by the Urban Councils Act (Chapter 29:15) that membership of the audit committee is strictly by council members. However, this requirement is not judiciously being adhered to as some local authorities in Zimbabwe have management personnel as members of audit committees (Jachi \& Yona, 2019a).

\subsection{The local government subsector regulatory environment}

The local government sub sector is mainly responsible for the delivery of basic services to local communities (Apollo, 2008). Public service delivery refers to the provision of services by public entities to its citizens, which are afforded regardless of class or economic status (Le Grand, 2009; Wanna, et al., 2010), meaning that the major tenets of a good public service are high quality and its equitable distribution. Public service delivery is funded by taxpayers, afforded without a profit motive and as such, it is not subjected to market forces. This effectively has a tendency to overshadow the incentive to create value for money for the taxpayer (Van Wheele, 2014), which is also complicated by the obscurity associated with performance measures for its administration. It is therefore the role of regulation to set the best premises to enable prevalence of good corporate governance practices to ensure there is creation of value and improvement in public service delivery (Vellapi, 2010). There are a number of pieces of legislation in Zimbabwe which authorize the establishment of audit committees within Zimbabwe local authorities. These include the Constitution (Amendment No. 20), the Public Finance Management Act (Chapter 
22:19), the Public Entities Corporate Governance Act (Chapter 10:31), the Urban Councils Act (Chapter 29;15) and the Rural District Councils Act (Chapter 29:13). All these pieces of legislation however do not specifically provide solid guidelines on the characteristics of the audit committees, except that majority of the members should be independent. This requirement is therefore well assured by the notion that local authorities operate on a committee system and the elected members of the council constitute members of the audit committees (Jachi \& Yona, 2019a).

\section{Conceptual framework}

Literature notes of various attributes which influence audit committee capacity to fulfill its mandate. Some of these attributes include the skills and competencies mix, the conduct of meetings and the extent to which the committee is free from management influence. These attributes play a pivotal role in determining the effectiveness of the audit committee's oversight role (Herdjiono \& Sari, 2017; Alqatamin, 2018). The relationship between the independent variable - audit committee characteristics and the dependent variable, internal audit effectiveness is illustrated below:

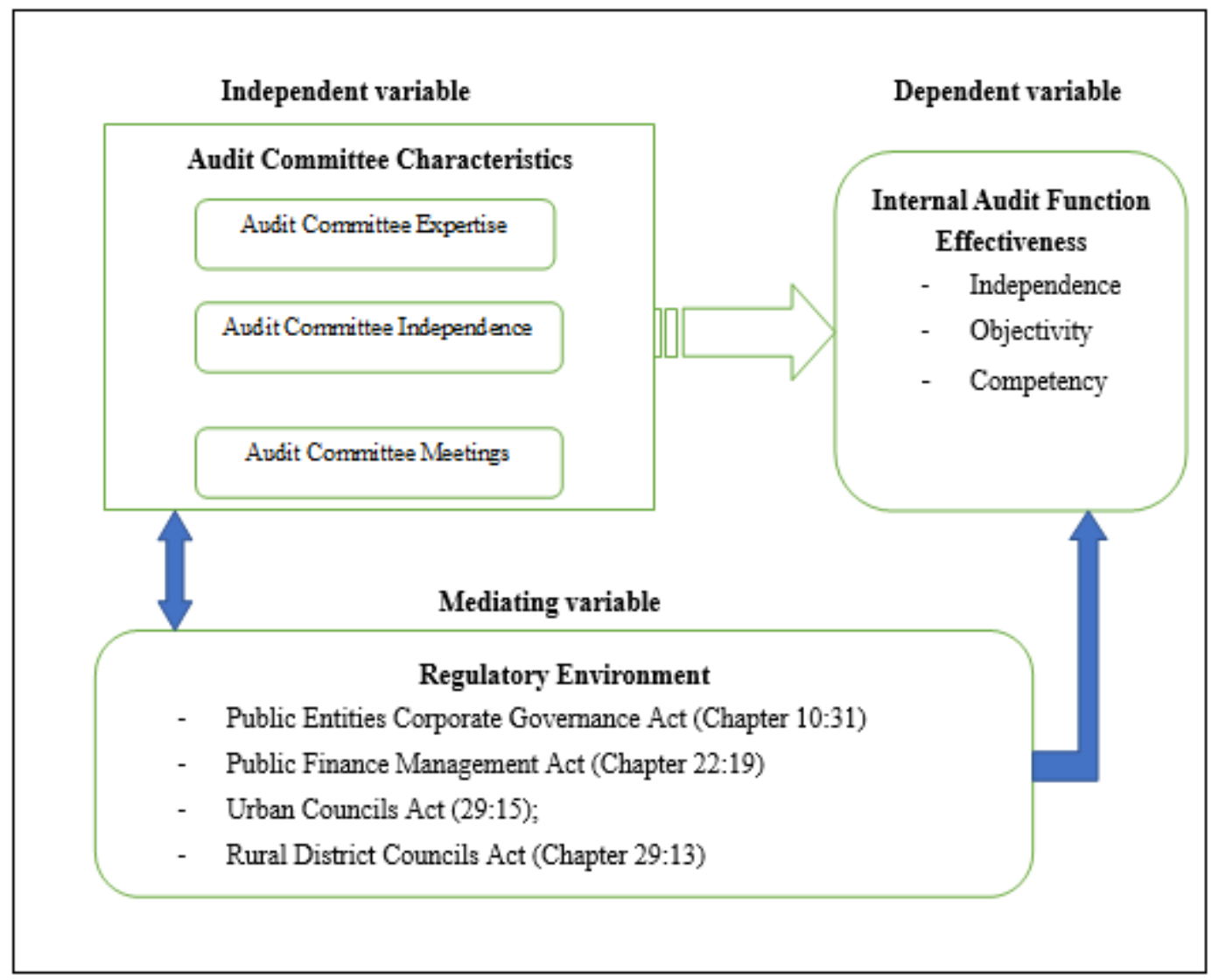

Figure 1: Study conceptual framework

Source: Researcher conceptualization, 2019

\section{Methodology}

The study adopted a quantitative approach, collection of primary data was done using semi-structured questionnaires. A documentary review of published literature on audit committees and internal audit and the Zimbabwean legislation was also conducted.

\subsection{Study hypothesis}

The study hypothesis was formulated on the basis of the need to enhance internal audit function effectiveness, to ensure the function actually adds value, through establishing premises to safeguard the function's independence, competency and objectivity. The relationship between audit committees and internal audit is emphasized in corporate governance codes, professional practice guidelines and even the legislation. Literature also notes that audit committees has a central responsibility to internal audit functions. They play an overseeing role over the function's activities and operations. Some of its specific responsibilities include the review and assessment of the internal audit function workplan, approval of appointment and termination of the head of the internal audit function, preservation of independence and checking on the effectiveness of the function (Carcello, 2002). The 
study therefore, aims to establish the influence of audit committee characteristics on internal audit function effectiveness in Zimbabwe local authorities. To assess the association between audit committee characteristics and internal audit function effectiveness dimensions, the study hypothesis was stated as:

H1: There is a positive relationship between audit committee characteristics and internal audit function effectiveness in Zimbabwe local authorities.

This study hypothesis has three sub-hypotheses stated hereunder:

H1a: There is a positive relationship between audit committees' expertise and internal audit function effectiveness

H1b: There is a positive relationship between audit committee independence and internal audit function effectiveness in Zimbabwe local authorities

H1c: There is a positive relationship between the manner in which audit committee meetings are conducted and internal audit function effectiveness in Zimbabwe local authorities.

\section{Findings}

6.1 Demographic variable

6.1.1 Level of education

Figure 2 below presents results on level of education of participants. The results indicate that $65 \%$ of the respondents have degrees, $21 \%$ had diplomas, $7 \%$ were certificate holders, while $7 \%$ were high school graduates composed of 3\% ordinary level and $4 \%$ advanced level graduates. These findings establish that many of the study participants were informed individuals. This has a positive impact on the results, through increasing their reliability, as participants are deemed educated enough to understand the phenomenon under study. These findings also suggest that local authorities in Zimbabwe employ based on academic merit.

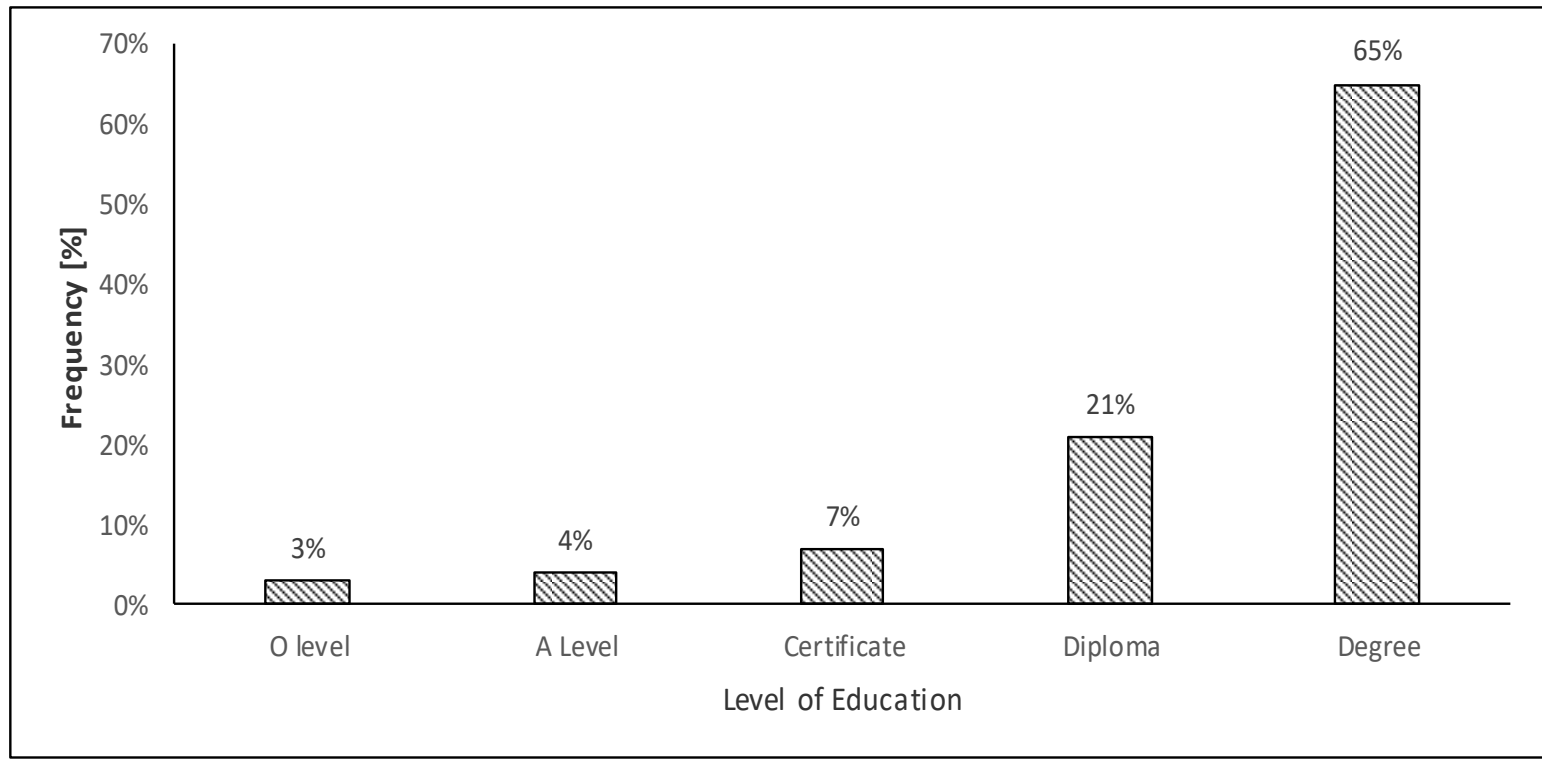

Figure 2: Level of education

Source: Researcher, 2019

\subsection{Hypothesis testing}

We test the relationship between audit committee attributes and internal audit effectiveness by using Pearson correlation analysis and regression analysis. We re-state the hypothesis hereunder:

H1: There is a negative relationship between audit committee characteristics and internal audit function effectiveness in Zimbabwe local authorities.

We also test the sub-hypotheses re-stated hereunder:

H1a: There is a negative relationship between audit committees' expertise and internal audit function effectiveness

H1b: There is a negative relationship between audit committee independence and internal audit function effectiveness in Zimbabwe local authorities

H1c: There is a negative relationship between the manner in which audit committee meetings are conducted and internal audit function effectiveness in Zimbabwe local authorities.

6.2.1. Correlation analysis

Correlation analysis is performed (Table 1) to show the relationship between audit committee attributes of 
expertise, independence and meetings (as the independent variable) and internal audit function effectiveness measured by its independence, competence and objectivity dimensions. The results indicate that there is a significant positive relationship between audit committee expertise and internal audit function independence of 0.268. the results also show that there is a significant relationship between audit committee expertise and internal audit function objectivity of 0.154 . However, the results also indicate that there is an insignificant relationship audit committee expertise and internal audit function competence. We therefore reject the null sub-hypothesis (H1a: There is a negative relationship between audit committees' expertise and internal audit effectiveness) and conclude that audit committee expertise positively internal audit function independence and objectivity.

Correlation analysis between audit committee attribute of independence and internal audit function effectiveness show that there is a significant positive relationship between audit committee independence and internal audit function independence of 0.096. the results also show that there is a significant negative relationship between audit committee independence and internal audit function competency of -0.281 . the results also show that there is an insignificant relationship between audit committee independence and internal audit function objectivity. We therefore reject the null sub-hypothesis (H1b: There is a negative relationship between audit committee independence and internal audit effectiveness in Zimbabwe local authorities) and conclude that audit committee independence is positively associated with internal audit function independence.

Correlation analysis between audit committee attribute of meetings and internal audit function effectiveness show that there is a significant positive relationship between audit committee meetings and internal audit function independence of 0.108 . there is also a significant positive relationship between audit committee meetings and internal audit function objectivity of 0.156 . However, the results show that there is an insignificant relationship between audit committee meetings and internal audit function competence. We therefore reject the null sub-hypothesis (H1c: There is a negative relationship between the manner in which audit committee meetings are conducted and internal audit function effectiveness in Zimbabwe local authorities) and conclude that the manner in which audit committee meetings are conducted positively influences internal audit function independence and objectiveness.

Table 1: Correlation between audit committee attributes and internal audit function effectiveness

\begin{tabular}{|c|c|c|c|c|c|c|}
\hline & $\begin{array}{l}\text { Expertis } \\
\mathrm{e}\end{array}$ & $\begin{array}{l}\text { Meeting } \\
\mathrm{S}\end{array}$ & $\begin{array}{l}\text { Independen } \\
\text { ce }\end{array}$ & $\begin{array}{l}\text { IAF } \\
\text { Independence }\end{array}$ & $\begin{array}{l}\text { IAF } \\
\text { Competence }\end{array}$ \\
\hline \multirow[t]{2}{*}{ Expertise } & $\begin{array}{l}\text { Pearson } \\
\text { Correlation }\end{array}$ & & & & & \\
\hline & Sig. (2-tailed) & & & & & \\
\hline \multirow[t]{2}{*}{ Meetings } & $\begin{array}{l}\text { Pearson } \\
\text { Correlation }\end{array}$ & -0.152 & & & & \\
\hline & Sig. (2-tailed) & 0.132 & & & & \\
\hline \multirow[t]{2}{*}{ Independence } & $\begin{array}{l}\text { Pearson } \\
\text { Correlation }\end{array}$ & 0.029 & 0.012 & & & \\
\hline & Sig. (2-tailed) & 0.774 & 0.908 & & & \\
\hline \multirow[t]{2}{*}{$\begin{array}{l}\text { IAF } \\
\text { Independence }\end{array}$} & $\begin{array}{l}\text { Pearson } \\
\text { Correlation }\end{array}$ & $.268 * *$ & $0.108 * *$ & $0.096^{*}$ & & \\
\hline & Sig. (2-tailed) & 0.007 & 0.00 & 0.03 & & \\
\hline \multirow[t]{2}{*}{$\begin{array}{l}\text { IAF } \\
\text { Competence }\end{array}$} & $\begin{array}{l}\text { Pearson } \\
\text { Correlation }\end{array}$ & 0.01 & 0.187 & $-.281 * *$ & -0.054 & \\
\hline & Sig. (2-tailed) & 0.92 & 0.063 & 0.005 & 0.596 & \\
\hline \multirow[t]{2}{*}{ AIF Objectivity } & $\begin{array}{l}\text { Pearson } \\
\text { Correlation }\end{array}$ & $0.154^{*}$ & $0.156 * *$ & $-0.166^{* *}$ & 0.158 & 0.195 \\
\hline & Sig. (2-tailed) & 0.001 & 0.00 & 0.01 & 0.116 & 0.052 \\
\hline
\end{tabular}

Source: Researcher, 2019

6.2.2. Regression analysis

Table 2 below indicate regression results for audit committee characteristics expressed in form of expertise, meetings and independence with positive results of expertise $(0.27)$, meetings $(0.115)$ and independence $(0.1)$, the results being significant at 0.05 level. This help us to conclude that audit committee expertise, meetings and independence can be used to predict the independence of an internal audit function. This leads us to the decision of rejecting the null hypothesis $\mathrm{H} 1$ that audit committee characteristics are not associated with internal audit function effectiveness. The table also indicate regression results for audit committee characteristics of expertise, meetings and independence, with results expertise (0.051), meetings (0.184) and independence $(-0.244)$. According to these findings, with only audit committee independence being significant at 0.05 level, we 
therefore conclude that audit committee independence helps us to better predict the competency of an internal audit function than audit committee expertise and meetings. This therefore leads us to the conclusion of rejecting the null hypothesis $\mathrm{H} 1$ that audit committee characteristics are not associated with internal audit function effectiveness. Table 2 below also indicate regression results for audit committee attributes of expertise, meetings and independence. These characteristics have Beta results of expertise (-0.134), meetings (0.194) and independence (-0.193). from these results it can be seen that meetings and independence results are significant at 0.05 level. This can help us to conclude that audit committee attributes of meetings and independence help in predicting the objectivity of an internal audit function than audit committee independence. This leads us to the decision of rejecting the null hypothesis $\mathrm{H} 1$ that audit committee characteristics are not associated with internal audit function effectiveness.

Table 2: Regression analysis - Audit committee characteristics and internal audit function effectiveness

\begin{tabular}{|c|c|c|c|c|c|c|}
\hline & & \multicolumn{2}{|c|}{ Unstandardized Coefficients } & Standardized Coefficients & \multirow[t]{2}{*}{$\mathrm{T}$} & \multirow[t]{2}{*}{ Sig. } \\
\hline \multirow[t]{5}{*}{ 1a } & Coefficients & $\mathrm{B}$ & Std. Error & Beta & & \\
\hline & (Constant) & 17.358 & 2.188 & & 7.934 & 0.000 \\
\hline & Expertise & 0.27 & 0.091 & 0.289 & 2.982 & 0.004 \\
\hline & Meetings & 0.115 & 0.095 & 0.118 & 1.201 & 0.000 \\
\hline & Independence & 0.1 & 0.082 & -0.118 & 1.215 & 0.007 \\
\hline \multirow[t]{4}{*}{$1 b$} & (Constant) & 13.762 & 2.452 & & 5.612 & 0.000 \\
\hline & Expertise & 0.051 & 0.102 & 0.048 & 0.501 & 0.617 \\
\hline & Meetings & 0.184 & 0.107 & 0.169 & 1.721 & 0.088 \\
\hline & Independence & -0.244 & 0.092 & -0.256 & -2.644 & 0.010 \\
\hline \multirow[t]{4}{*}{$1 \mathrm{c}$} & (Constant) & 11.859 & 2.473 & & 4.795 & 0.000 \\
\hline & Expertise & -0.134 & 0.103 & -0.128 & -1.309 & 0.194 \\
\hline & Meetings & 0.194 & 0.108 & 0.178 & 1.793 & 0.006 \\
\hline & Independence & -0.193 & 0.093 & -0.204 & -2.069 & 0.041 \\
\hline & $\begin{array}{ll}\text { a. Dependent } \\
\text { b. Dependent } \\
\text { c. Dependent }\end{array}$ & $\begin{array}{l}\text { ariable: } \\
\text { ariable: } \\
\text { ariable: }\end{array}$ & $\begin{array}{l}\text { dit Functio } \\
\text { dit Functio } \\
\text { dit Functio }\end{array}$ & $\begin{array}{l}\text { pendence } \\
\text { petence } \\
\text { ctivity }\end{array}$ & & \\
\hline
\end{tabular}

Source: Researcher, 2019

From the regression analysis results, we can therefore conclude that there is a significant positive relationship between audit committee attributes and internal audit function effectiveness in Zimbabwe local authorities.

\section{Discussion}

Internal audit plays a paramount role in organizational governance practices (IIA, 2016) and this is well documented in both professional and academic literature (IIA, 2016; West, 2017; Dal Mas \& Barac, 2018). Literature also notes that a number of factors, however, influence the effectiveness of internal audit functions in fulfilling their mandates. These factors are the main dimensions driving the function's quality, and they include the practitioners' ethical decision making ability (Woodbine \& Liu, 2010; West, 2017), which significantly determines the function's objectiveness (Jachi \& Yona, 2019b), the function's competencies mix (Endaya \& Hanefah, 2013; Lenz \& Hahn, 2015; Abbott, et al., 2016; Jachi \& Yona, 2019c) and the ability and capacity of the function to resist management influence (Kimotho, 2014; Roussy \& Brivot, 2016; Al-Shabail \& Turki, 2017; Jachi \& Yona, 2019a). It can be noted from this handful of literature that one of the key factors in enhancing the quality and effectiveness of internal audit functions is the role played by audit committees. Audit committees through their oversight role (Alqatamin, 2018), contribute significantly towards shaping the governance tone of the organization, by complementing and strengthening internal audit functions. However, the degree of influence of the committee also dependent on its attributes, the main ones being the committee's expertise mix (Aldamen, et al., 2012; Enofe, et al., 2013), independence (Nekhili, et al., 2016; Naimah, 2017; Alqatamin, 2018) and the conduct of the committee's meetings (Jackling \& Johl, 2009; Hsu \& Petchsakulwong, 2010; Alqatamin, 2018). These attributes are key in determining the capacity of the audit committee to influence the effectiveness of internal audit function and directing the overall governance tone of the entire organization.

In line with a handful of prior studies, results from the current study confirm that audit committee expertise positively influences internal audit function independence and objectivity. The study also established that audit committee independence directly influences internal audit function independence. It was further confirmed that the manner in which audit committee meetings are conducted, has a direct implication on internal audit function independence and objectivity. In line with prior study findings, the study confirms that during selection of audit committee membership in Zimbabwe local authorities, no consideration is made to the expertise and profile of the members, as it is more of a political than a professional process (Jachi \& Yona, 2019a), findings also 
establish that management personnel are members of and mandatorily attend audit committee meetings in selected local authorities, thereby negatively impacting the capacity of audit committees to effectively execute their mandate. Study results establish that all audit committee members in Zimbabwe local authorities are council members elected in to office and except for a few cases including local authority's management personnel. Majority of the members have academic qualifications, the least qualified being high school graduates, pointing to their capacity to read and write. Literature however call for the need for audit committees to have accounting and financial expertise or a relative mix thereof, and being an expert takes more than financial literacy, which is the ability to read and understand financial statements. Being an expert takes exposure in accounting, finance and audit, and being in possession of professional qualifications and certifications (Carcello, 2002). The appointment of political figures into audit committee membership without consideration of expertise and personal profiles to assess capabilities will end up making the audit committees more of symbolical functions (Kalbers \& Fogarty, 1993), which adds no actual value to the governance processes and practices of the organization.

\section{Conclusion}

The study explored the influence of audit committee attributes on internal audit function effectiveness in Zimbabwe local authorities. The study established that audit committee membership in Zimbabwean local authorities is dominated by elected council members, and management personnel in some selected few local authorities. Expertise, competencies and personal professional profiles are not taken into consideration when considering individuals for audit committee membership in Zimbabwe local authorities. The study also established that, notwithstanding clear pronouncements by statute in contrary, management personnel in selected local authorities mandatorily attend audit committee meetings. The study correlation and regression analysis results deduce that audit committee attributes of expertise, independence and conduct of meetings have the capacity to influence internal audit function effectiveness. As such, taking cognizance of the fact that local authorities are 'political' institutions, the study recommends the inclusion of financial experts as ex-officio members of the audit committees. Preferably, these can be professional members of the civil service with the relevant expertise, professional qualifications and certifications in finance, accounting or audit, to act as resource persons guiding the committees and informing its decisions and operations. The study also recommends the establishment of clear guidelines guiding the operations of audit committees of local authorities in Zimbabwe.

\section{References}

Abbott, L. J., Daugherty, B., Parker, S. \& Peters, G. F., 2016. Internal audit quality and financial reporting quality: The joint importance of independence and competence. Journal of Accounting Research, 54(1), pp. 3-40.

Abbott, L. J. \& Parker, S., 2000. Audit selection and audit committee characteristics. Auditing: A Journal of Practice \& Theory, 19(2), pp. 47-66.

Abbott, L. J., Parker, S., Peters, G. F. \& Raghunandan, K., 2003. An empirical investigation of audit fees, non0audit fees and audit committees. Contemporary Accounting Research, 20(2), pp. 215-234.

Akhigbe, A. \& Martin, A. D., 2006. Valuation impact of Sarbanes-Oxley: Evidence from disclosure and governance within the financial service industry. Journal of Banking \& Finance, 30(3), pp. 989-1006.

Aldamen, H. et al., 2012. Audit committee characteristics and firm performance during the global financial crisis. Accounting and Finance, 5(24), pp. 971-1000.

Al-Matari, E. M., Al-Swidi, A. K. \& Fadzil, F. H. B., 2014. Audit committee characteristics and executive committee characteristics and firm performance in Oman: Empirical study. Asian Social Science, 10(12), pp. 98-113.

Al-Matari, Y. A. et al., 2012. Board of directors, audit committee characteristics and perfromance of Saudi Arabia Listed Companies. International Review of Management and Marketing, Volume 24, p. 241.

Al-Matari, Y. A. T., 2013. Board of directors, audit committee characteristics and the performance of public listed companies in Saudi Arabia, s.1.: Universiti Utara Malaysia.

Al-Moataz, E. \& Hussainey, K., 2012. Determinants of corporate governance disclosure in Saudi Arabia. King Abdulaziz University Journal of economics and Administration, 27(2), pp. 411-430.

Alqatamin, R. M., 2018. Audit committee effectiveness and company performance: Evidence from Jordan. Accounting and Finance Research, 7(2), pp. 48-60.

Al-Shabail, A. M. \& Turki, A. A. T., 2017. A theoretical discussion of internal audit effectiveness in Kuwaiti Industrial SMEs. International Journal of Academic Research in Accounting, Finance and Management Sciences, 7(1), pp. 107-116.

Apollo, M., 2008. Impact assesment of the local government reforms in Rwanda. The case study of Kigali City. Port Elizabeth: s.n.

Avison, L. \& Cowton, C. J., 2012. UK audit committees and the revised code. Corporate Governance. The 
International Journal of Business in Society, 12(1), pp. 42-53.

Badolato, P. G., Donelson, D. C. \& Ege, M., 2014. Audit committee financial expertise and earnings management: The role of status. Journal of Accounting and Economics, 58 (2-3), pp. 208-230.

Basley, T. \& Ghatak, M., 2007. Rerforming public service delivery. Journal of African Economies, 16(1), pp. 127-156.

Beasley, M. S., Carcello, J. V., Hermanson, D. R. \& Neal, T. L., 2010. Fraudulent financial reporting: 19982007. An analysis of US public companies, Durham, North Carolina: COSO.

Chan, R. S. Y., Lau, C. K. S. \& Ng, A. W., 2011. Compliance and value relevance of audit committees: Evidence from Hong Kong.. Journal of Financial Reporting and Accounting, 9(1), pp. 74-97.

Chirisa, T., 2010. Social development in Zimbabwe. Discussion paper prepared for the Development Foundation for Zimbabwe. s.1.:s.n.

Cohen, J., Krishnamoorthy, G. \& Wright, A. M., 2002. Corporate governance and the audit process. Contemporary Accounting Research, 19(4), pp. 573-594.

Dal Mas, L. O. \& Barac, K., 2018. The influence of chief audit executive's leadership style on factors related to internal audit effectiveness. Managerial Auditing Journal, 33(8/9), pp. 807-835.

Dellaportas, S. et al., 2012. Audit committee effectiveness and timeliness of reporting: Indeonesian evidence.. Managerial Auditing Journal, 27(4), pp. 403-424.

DeZoort, F. T., 1997. An investigation of audit committees' oversight responsibilities. Abacus, 33(2), pp. 208227.

Dhaliwal, D., Naiker, V. \& Navissi, F., 2010. The association between accruals quality and the characteristics of accounting experts and mix of expertise on audit committees. Contemporary Accounting Research, 27(3), pp. 787-827.

Endaya, K. A. \& Hanefah, M. M., 2013. Internal audit effectiveness: An approarch position to develop the theoretical framework. Research Journal of Finance and Accounting, 4(10), pp. 92-102.

Enofe, A. O., Aronmwan, E. J. \& Abadua, H. S., 2013. Audit committee report in corporate financial statements: User perception in Nigeria. European Journal of Accounting and Finance Research, 1(1), pp. 16-28.

Fama, E. \& Jensen, M., 1983. Seperation of ownership and control. Journal of Law and Economics.

Ghabayen, M. A., 2012. Board characteristics and firm performance: Case of Saudi Arabia. International Journal of Accounting and Financial Reporting, 2(2), pp. 168-200.

Ghabayen, M. A., 2012. Board characteristics and firm performance: Case of Saudi Arabia. International Journal of Accounting and Financial Reporting, 2(2), pp. 168-200.

Goddard, A. R. \& Masters, C., 2000. Audit committees, Cadbury code and audit fees: An empirical analysis of UK companies. Managerial Auditing Journal, 15(7), pp. 358-371.

Guy, D. M. \& Zeff, S. A., 2002. Independence and objectivity: Retired partners on audit committee. $C P A$ Journal, July, pp. 31-34.

Habbash, M., 2015. Audit committee effectiveness and audit quality: Evidence from Saudi Arabia. International Journal of Management and Applied Science, 1(7), pp. 5-14.

Hamid, A. \& Aziz, R., 2012. Impact of the amendments of Malaysian code of corporate governance (2007) on governance of GLCs performance. International Journal of Economics and Management Engineering, 6(11), pp. 3181-3186.

Herdjiono, I. \& Sari, I. M., 2017. The effect of corporate governance on the performance of a company. Some empirical findings from Indonesia. Journal of Management and Business Administration, 25(1), pp. 33-52.

Hsu, W. Y. \& Petchsakulwong, P., 2010. The impact of corporate governance on the efficiency performance of the Thai non-life insurance industry. Geneva Papers on Risk and Insurance - Issues and Practices, 35(1), pp. S28-S49.

IIA, 2016. Definition of Internal Auditing. USA: Institute of Internal Auditors.

International Republican Institute, 2015. Survey on local governance and constitutionalism in Zimbabwe. s.1.:International republican Institute on Advanced Democracy World wide.

Jachi, M. \& Yona, L., 2019a. The Impact of Independence of internal audit function on transparency and accountability. Case of Zimbabwe local authorities. Research Journal of Finance and Accounting, 10(5), pp. 64-77.

Jachi, M. \& Yona, L., 2019b. The impact of ethics and objectivity of internal audit personnel on transparency and accountability. Case of Zimbabwe local authorities. European Journal of Business and Management, 11(7), pp. 108-124.

Jachi, M. \& Yona, L., 2019c. The impact of professional competence and staffing of internal audit function on transparency and accountability. Case of Zimbabwe local authorities. Research Journal of Finance and Accounting, 10(8), pp. 149-164.

Jackling, B. \& Johl, S., 2009. Board structure and firm performance: Evidence from India's top companies. Corporate Governance: An International Review, 17(4), pp. 493-508. 
Jensen, M. \& Meckling, W. H., 1976. Theory of the firm: Managerial behaviour, agencycosts and ownership structure. Journal of Financial Economics, 3(4), pp. 305-360.

Jun Lin, Z. X. J. Z. \& Tang, Q., 2008. The roles, responsibilities and characteristics of audit committee in China. Accounting, Auditing \& Accountability Journal, 21(5), pp. 721-751.

Kalbers, L. P. \& Fogarty, T. J., 1993. Audit committee effectiveness: An empirical investigation of the contribution of power. Auditing, 12(1), p. 24.

Kallamu, B. S. \& Saat, N. A. M., 2015. Audit committee attributes and firm performance: Evidence from Malaysian finance companies. Asian Review of Accounting, 23(3), pp. 206-231.

Kallamu, B. S. \& Saat, N. A. M., 2015. Audit committee attributes and firm performance: Evidence from Malaysian finance companies.

Khlif, H. \& Samaha, K., 2016. Audit committee activity and internal control quality in Egypt: Does external auditor's size matter?. Managerial Auditing Journal, 31(3), pp. 269-289.

Kimotho, N. T., 2014. Factors affecting internal audit independence: A case study of Technical University of Mombasa. Journal of Business Management, 6(6).

Krishnan, G. V. \& Visvanathan, G., 2008. Does the SOX definition of an accounting expert matter? The association between audit committee directors' accounting expertise and accounting conservatism. Contemporary Accounting Research, 25(3), pp. 827-857.

Krishnan, J., 2005. Audit committee quality and internal control: An empirical analysis. The Accounting Review, 80(2), pp. 649-675.

Larry, A. M. \& Taylor, D. W., 2012. Governance characteristics and role effectiveness of audit committes. Manegerial Auditing Journal, 27(4), pp. 336-354.

Le Grand, J., 2009. The other invisible hand: Delivering public service through choice and competition. Princeton: Princeton University Press.

Lee, G. \& Fargher, N. L., 2018. The role of audit committee in their oversight of whistle-blowing.. Auditing: A Journal of Practice \& Theory, 37(1), pp. 167-189.

Lenz, R. \& Hahn, U., 2015. A sythesis of empirical internal audit effectiveness literature pointing to new research opportunities. Managerial Auditing Journal, 30(1), pp. 5-33.

Lin, J., Li, J. F. \& Yang, J. S., 2006. The effect of audit committee performance on earnings quality. Managerial Auditing Journal, 21(9), pp. 921-933.

Lipton, M. \& Lorsch, J., 1992. Modest proposal for improved corporate governance. Business Lawyer, 12(3), pp. 48-59.

Max, B., 2009. An analysis of audit committee effectiveness at the largest listed companies in South Africa from the CFO and AC perspective. Acta Comercii, Volume 9, pp. 13-23.

Mohd, A. M. N., 2011. The effects of implementation of Malaysia code of corporate governance (MCCG) 2007 on corporate governance attributes and financial performance. s.1.:PhD DPA Dissertation, University Utare Malaysia.

Murimoga, R. \& Musingafi, M. C. C., 2014. Local governance and service delivery in Zimbabwe local authorities the case of Harare and Masvingo urban municipalities. International Journal of Public Policy and Administration Research, 1(3), pp. 94-107.

Naimah, Z., 2017. The role of corporate governance in firm performance. s.1., SHS Web of Conferences.

Nekhili, M. et al., 2016. R \& D narrative disclosure, corporate governance and market value: Evidence from France. Journal of Applied Business Research, 32(1).

Psaros, J. \& Seamer, M., 2004. Australian audit committees. Do they meet best practice guidelines?. Australian Accounting Review, Volume 14, pp. 77-85.

Rabab'ah, M., Al-Sir, O. \& Alzoubi, A., 2017. The impact of audit committees' properties on the quality of the information in the banking financial reports: A survey on Saudi commercial banks. International Business Research, 10(11), pp. 175-192.

Roussy, M. \& Brivot, M., 2016. Internal audit quality: A polysemous notion?. Accounting, Auditing and Accountability Journal, 29(5), pp. 714-738

Saleh, N. M., Iskandar, T. M. \& Rahmat, M. M., 2007. Audit committee characteristics and earnings management: Evidence from Malaysia. Asian Review of Acounting, 15(2), pp. 147-163.

Sharma, V., Naiker, V. \& Lee, B., 2009. Determinants of audit committee meeting frequency: Evidence from a voluntary government system.

Turley, S. \& Zaman, M., 2004. The corporate governance effects of audit committees. Journal of Management and Governance, 8(3), pp. 305-332.

Vafeas, N., 1999. Board meetings frequency and firm performance. Journal of Financial Economics, 53(1), pp. 113-142.

Van der Nest, D. P., 2005. Audit committee in government departments: An internal audit perspective. South Africal Journal of Accountability and Auditing Research, Volume 6, pp. 75-84. 
Van Wheele, A. J., 2014. Purchasing and supply chain management. 6th ed. Singapore: Cengage Learning

Vellapi, M., 2010. Public procurement for sustainable development. Research paper on sustainable public procurement. SriLanka: Minstry of Highways.

Wanna, J., Butcher, J. \& Freyens, B., 2010. Policy in Action: The challenges of service delivery. Sydney: New South Publishing.

Weishaar, E., 2013. Cartels, competition and public procurement: Law and Economic approaches to bid rigging. Chelteham: Edward Elgar.

West, A., 2017. The ethics of professional accountants: An aristotelian perspective. Accounting, Auditing and Accountability Journal, 30(2), pp. 328-351.

Woodbine, F. G. \& Liu, J., 2010. Leadership styles and the moral choice of internal auditors. Electronic Journal of Business Ethics and Organisation Studies, 15(1), pp. 28-35.

Xie, B., Davidson III, W. N. \& Da Dalt, P. J., 2003. Earnings management and corporate governance: The role of the board and the audit committee. Journal of Corporate Finance, 9(3), pp. 296-315.

Yeh, Y. H., Chung, H. \& Liu, L. C., 2011. Committee independence and financial institution performance during the 2007-08 credit crunch: Evidence from multi-country study. Corporate Governance: An International Review, 19(5), pp. 437-458.

Zibra, S. M., Ahmad, K. \& Wah, K. K., 2016. Corporate governance practices and firm performance: Evidence from top 100 Public Listed Companies in Malaysia. Procedia Economics and Finance, Volume 35, pp. $287-$ 296. 